\title{
New hosts for Lecanosticta acicola and Dothistroma septosporum in Spain
}

\author{
Nebai Mesanza 1, Rosa Raposo 2,3 Margarita Elvira-Recuenco 2, Laura Hernandez-Escribano ${ }^{2}$, \\ Irene Barnes ${ }^{4}$, Ariska van der Nest ${ }^{4}$, María Teresa Pascual 5, Iskander Barrena 5, Unai San Martín \\ ${ }^{6}$, Alejandro Cantero ${ }^{6}$ and Eugenia Iturritxa ${ }^{1 *}$ \\ 1 Forest Science, Neiker Tecnalia, Apartado 46, Vitoria Gasteiz 01080, Spain; \\ eiturritxa@neiker.eus (E.I.); nebaimesanzaiturritza@gmail.com (N.M.) \\ 2 Silviculture and Forest Management Department, Forest Research Center (CIFOR), Instituto Nacional de \\ Investigación y Tecnología Agraria y Alimentaria (INIA), Madrid, Spain. \\ ${ }^{3}$ Instituto de Gestion Forestal Sostenible (iuFOR), Universidad de Valladolid/INIA, Spain. \\ ${ }^{4}$ Department of Biochemistry, Genetics and Microbiology, Forestry and Agricultural Biotechnology Institute, \\ University of Pretoria, Pretoria, South Africa. \\ ${ }^{5}$ Bizkaiko Basalan Azkiozko Baltzua Ab Sa. Madariaga Etorbidea, 1, 48014 Bilbo, Bizkaia. \\ ${ }^{6}$ Hazi fundatzioa, Granja Modelo s/n 01192 Arkaute Álava \\ * Correspondence: nmesanza@neiker.eus, eiturritxa@neiker.eus (E.I.); Tel.: +34-637-436-343 (E.I.)
}

\section{Abstract}

The largest impact of needle diseases in the recorded history of Pinus radiata and Pinus nigra plantations in the North of Spain, was from 2018 to 2019. The severity of the disease has led to a serious reconsideration of forest management in the area. The main pathogens involved in this historical outbreak were Lecanosticta acicola and Dothistroma septosporum. Three arboreta were established under the European project REINFFORCE in the Basque Country in recently harvested $P$. radiata plantations. The plants for the arboreta were produced in nurseries located in the Alps of Upper Provence (France). These arboreta were surrounded by plantations seriously damaged by $L$. acicola and D. septosporum. The Pinus species which were sampled in the arboreta included P. brutia (4 provenances), P. elliottii (2 provenances), P. nigra (8 or 9 provenances), P. pinaster (7 provenances), P. pinea (6 provenances), P. ponderosa (3 provenances), $P$. sylvestris (8 provenances) and P. taeda (3 provenances). Lecanosticta acicola is reported for the first time infecting Pinus brutia (Provenance: Alexandropolis, Greece and var. eldarica, Crimea), a new host species for this pathogen. Pinus elliottii (Provenance: Georgia, USA) and P. ponderosa (Provenance: Central California, USA) are new host reports of L. acicola for Spain. Dothistroma septosporum was found for the first time on P. brutia (Provenance: Marmaris, Turkey) and P. ponderosa (Provenance: Oregon, USA) in Spain and was also detected infecting P. nigra (Provenance: Slogne Vayrières, France).

Keywords: BSNB, defoliation, Dothistroma needle blight, Mycosphaerella dearnessii

\section{Introduction}

The incidence of Lecanosticta acicola (Thüm.) Syd., causal agent of brown spot needle blight (BSNB), and Dothistroma septosporum (Dorog.) Morelet and D. pini Hulbary, the causal agents of red band needle blight (DNB), have increased during the last decades in Europe [1,2]. The first reports of Dothistroma spp. and L. acicola in Spain were in 1933 and 1942 respectively [3,4]. However, the highest impact of disease severity ever recorded on Pinus radiata D. Don and Pinus nigra Arnold 
plantations in the North of Spain was from 2018 to 2019. High defoliation levels, and the unusual mortality rate, has caused an economic, environmental and social alarmism that has questioned the efficacy of current management strategies carried out in forest plantations.

Lecanosticta acicola and Dothistroma spp. have a broad host range and are found in several countries around the world. The presence of L. acicola and Dothistoma spp. has been detected on 53 and 96 different Pinus species, including hybrids, respectively [2,5,6]. At least two putative introductions of L. acicola have occurred in Europe from North America [7]. Its intercontinental introduction can most likely be explained as a consequence of the movement of infected plant material $[7,8]$. The spread of L. acicola within Europe appears to be associated with conidial dispersion and ascospore dissemination and also to accidental, human mediated introductions $[7,8]$. This species is included in the EPPO A2 list. In Spain, L. acicola has been reported on P. radiata, $P$. sylvestris L. and P. nigra; D. septosporum on P. radiata, P. sylvestris, P. nigra, P. pinaster Ait. and Pseudotsuga menziesii (Mirb.) Franco, and D. pini on P. nigra [6,9].

An important group of organisms causing similar symptoms to the brown spot and red bands on pine, are those belonging to Phytophthora. Phytophthora pluvialis Reeser, Sutton, and E. Hansen was reported as a new defoliating disease in Pinus radiata and Pseudotsuga menziesii in New Zealand [10]. Phytophthora pinifolia Alv. Durán, Gryzenh. and M.J. Wingf. was detected in 2004 in P. radiata plantations in central Chile [11] and in 2006, a total of 60,000 trees were reported to be affected. These days however, the disease is not causing significant damage and symptoms are only observed on sporadic trees [12]. Both Phytophthora species may produce common symptoms such as olive-coloured bands on needles, dark resinous spots and reddening and cast of infected needles. In addition, infections by P. pinifolia cankers may appear at the base of the needle fascicle [11,13]. Although these Phytophthora spp. species are considered absent in the EPPO region, and were removed from the EPPO Alert List in 2013, it cannot be ruled out that the severe damage observed in Pinus in the Basque country might also be due to a newly introduced Phytophthora spp., and this would need to be investigated.

As part of a wider monitoring plan carried out to determine the possible causes of the most explosive emergence of a forest disease in the North of Spain, arboreta located next to pine plantations with similar severe symptoms of defoliation were examined. These arboreta were established under the European project REINFFORCE in the Basque Country in recently harvested P. radiata plantations. Two of them, with an average size of $3 \mathrm{Ha}$ each, are located in Albinabehea (Aramaio, Araba, AR24) and Irisasi (Usurbil, Gipuzkoa, AR22). The third arboretum, 6 Ha in size, is located in Laukiz (Bizkaia, AR20) (Figure 1). The plants in the arboreta were produced in two nurseries placed in the Alps of Upper Provence (France) during 2011 and 2012, and in a nursery located in Guémené (France) in 2013. The material was subjected to phytosanitary controls and it was planted in the winters of 2011, 2012 and 2013. Common European tree species and alternative ones, including several provenances with between five to 12 trees per provenance, were planted in order to determine their adaptability to climate change. After being established for six years, severe needle defoliation was observed. The arboreta were located in an area of oceanic climate and at distances of less than 100 meters from plantations of Pinus radiata and Pinus nigra, in which the presence of Lecanosticta acicola and Dothistroma septosporum was previously confirmed [9]. 
The aim of the present study was to characterise the main defoliating disease agents in these new established arboreta which are of great interest due to the diversity of the Pinus species and provenances.

\section{Materials and Methods}

\subsection{Sample collection and fungal identification.}

Needle samples from a total of 74 pine trees located in the arboreta of Albinabehea (Araba), Irisasi (Gipuzkoa) and Laukiz (Bizkaia) were collected (Figure 1). A minimum of $100 \mathrm{~g}$ of needles per tree were collected from both symptomatic and asymptomatic trees. Defoliation was estimated using a severity degree scale for each tree using the 5\% step method (1: <25\% 2: $25-<50 \%$; $3: 50$ $<75 \% ; 4: \geq 75 \%$ ) [14] (Figure 2). The tree species sampled included P. brutia Ten. (4 provenances), $P$. elliottii Engelm. (2 provenances), P. nigra (8 or 9 provenances), P. pinaster Ait. (7 provenances), $P$. pinea L. (6 provenances), P. ponderosa Douglas ex C. Lawson (3 provenances), P. sylvestris L. (8 provenances) and $P$. taeda (3 provenances). Trees were sampled regardless of whether they exhibited symptoms of defoliation or not Table 1). All samples were visually inspected for any symptoms resembling spots or bands with fruiting bodies.

A

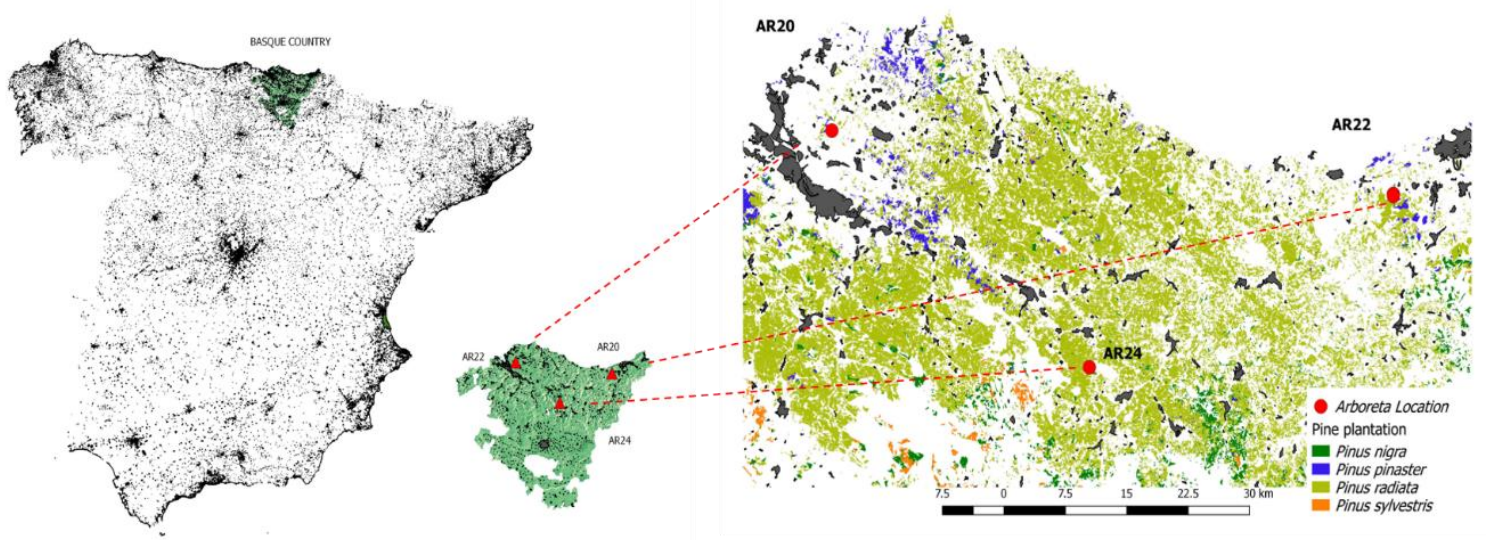

Figure 1. Locations of the three arboreta (AR20, AR22 and AR24) in the Basque Country from which samples were collected for this study (A). Species of pine plantations surrounding the arboretum environment (B). 
A

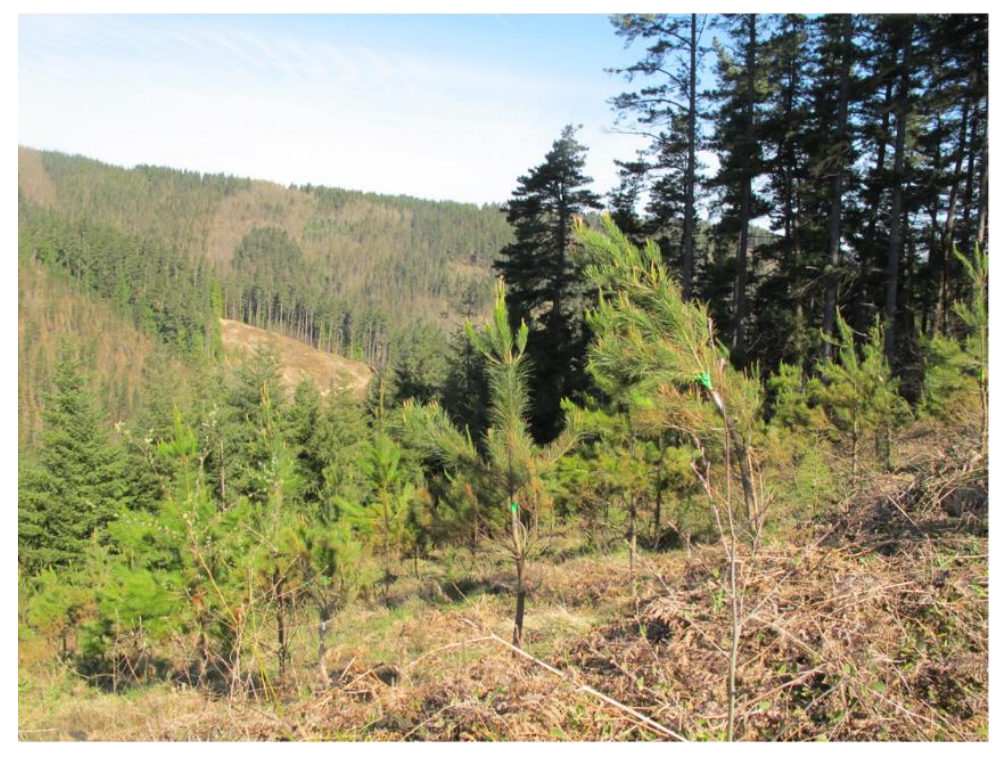

B

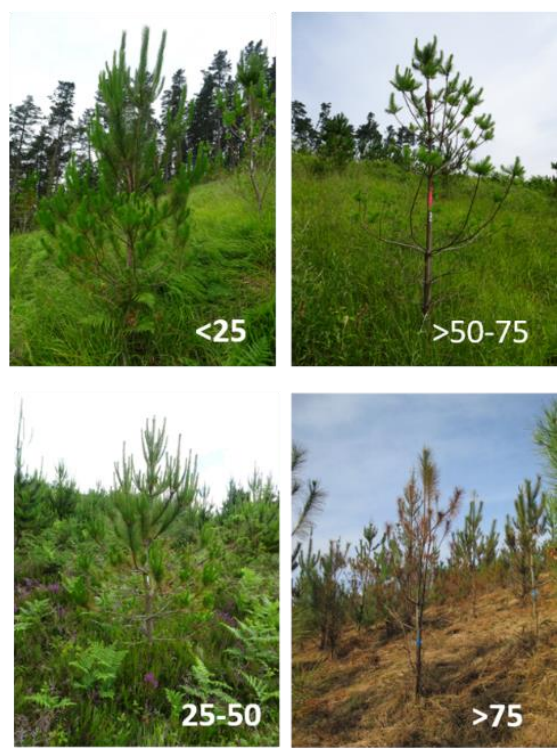

Figure 2. Severe outbreak in adult and young plantations located next to the arboretum (A). Score system applied in the defoliation evaluation (B).

DNA was extracted directly from a $100 \mathrm{mg}$ sample per tree of symptomatic and asymptomatic trees with the innuPREP Plant DNA Mini Kit (Analytic Jena AG, Jena, Germany). The presence of $L$. acicola, D. septosporum and D. pini was determined by species-specific conventional PCR using 0.4 $\mu \mathrm{M}$ of each primer (LAtef.F/LAtef.R, DStub2-F/DStub2-R or DPtef-F/DPtef-R) [15], 10x buffer (Complete II KCl Buffer, IBIAN technologies, Zaragoza, Spain), $200 \mu \mathrm{M}$ dNTP, 0.5 U Taq DNA Polymerase (IBIAN technologies), and $1.5 \mu \mathrm{L}$ DNA template in a total volume of $20 \mu \mathrm{L}$. The PCR conditions were as follows: $10 \mathrm{~min}$ at $94{ }^{\circ} \mathrm{C}, 35$ cycles of $30 \mathrm{~s}$ at $94{ }^{\circ} \mathrm{C}, 30 \mathrm{~s}$ at $60{ }^{\circ} \mathrm{C}$, and $45 \mathrm{~s}$ at $72{ }^{\circ} \mathrm{C}$, and a final $10 \mathrm{~min}$ at $72{ }^{\circ} \mathrm{C}$. PCR amplicons were visualised on a $2 \%$ agarose gel (Conda, Madrid, Spain) stained with GelRed ${ }^{\circledR}$ (Biotium Inc., California, USA). The reactions were considered positive for D. septosporum, D. pini and L. acicola if amplicon sizes measured $231 \mathrm{bp}, 193 \mathrm{bp}$ and 237 bp respectively.

The detection of Phytophthora species was carried out by commercial enzyme immunoassays using the Phytophthora ImmunoStrip ${ }^{\circledR}$ Test (AGDIA Inc., Indiana, USA), which is recommended as a preliminary screening tool in survey programs for Phytophthora species. ImmunoStrips ${ }^{\circledR}$ and extraction buffer were warmed to room temperature $\left(18-30^{\circ} \mathrm{C}\right)$ before use. $150 \mathrm{mg}$ of each needle sample was placed in the extraction bag containing $3 \mathrm{~mL}$ of extraction buffer and macerated and crushed with a tissue homogenizer. The ImmunoStrip ${ }^{\circledR}$ was inserted into the bag and submerged in the extract for 30 minutes, after which results were recorded.

\section{Results}

Symptoms of defoliation were mainly located in the lower half of the tree. Despite the high level of defoliation, in the majority of the cases, no visible fungal fruiting bodies of needle blight species were observed.

From 74 samples analyzed, four resulted in positive amplifications for Lecanosticta acicola and three for Dothistroma septosporum. Positive results for D. septosporum were only found in the samples 
collected from Irisasi arboretum, on P. brutia (Marmaris, Turkey), P. nigra (Slogne Vayrières, France) and P. ponderosa (Oregon, USA) with levels of defoliation scored 1, 3 and 4 respectively. Lecanosticta acicola was detected in all three arboreta, in needle samples from $P$. elliottii (Georgia, USA), $P$. ponderosa (Central California, USA), P. brutia (Alexandropolis, Greece) and P. brutia (var. eldarica, Crimea) with estimated defoliation of $4,3,1$, and 3 (Table 1). None of the tested samples yielded a positive result for D. pini or Phytophthora sp.

Table 1. Detection of Dothistroma septosporum and Lecanosticta acicola in relation to location (arboretum) and Pinus species, provenance, age (in years) and level of defoliation.

\begin{tabular}{|c|c|c|c|c|c|c|c|}
\hline $\begin{array}{l}\text { Sample } \\
\text { ID }\end{array}$ & Location & Species & Provenance & Age & $\begin{array}{c}\text { Defoliation } \\
\text { level }\end{array}$ & L. acicola & D. septosporum \\
\hline 23 & Albina & P. brutia & Taurus, Turkey & 7 & 1 & 0 & 0 \\
\hline 18 & Albina & P. brutia & var. eldarica, Crimea & 7 & 2 & 0 & 0 \\
\hline 42 & Albina & P. elliottii & Georgia, USA & 5 & 3 & 0 & 0 \\
\hline 37 & Albina & P. elliottii & Georgia, USA & 6 & 4 & 1 & 0 \\
\hline 32 & Albina & P. elliottii & Louisiana, USA & 7 & 3 & 0 & 0 \\
\hline 36 & Albina & P. nigra & Cazorla Alcaraz, Spain & 6 & 1 & 0 & 0 \\
\hline 26 & Albina & P. nigra & Les Barnes Sivens, France & 7 & 2 & 0 & 0 \\
\hline 35 & Albina & P. nigra & $\begin{array}{l}\text { Sistema Iberico Meridional, } \\
\text { Spain }\end{array}$ & 6 & 1 & 0 & 0 \\
\hline 34 & Albina & P. nigra & Slogne Vayrières, France & 7 & 1 & 0 & 0 \\
\hline 27 & Albina & P. nigra & $\begin{array}{l}\text { subsp. laricio var. corsican, } \\
\text { Haute Serre seed tree orchard, } \\
\text { France }\end{array}$ & 7 & 1 & 0 & 0 \\
\hline 39 & Albina & P. nigra & subsp. salzmannii, Soria, Spain & 5 & 1 & 0 & 0 \\
\hline 21 & Albina & P. pinaster & Mimizan, Landes, France & 7 & 1 & 0 & 0 \\
\hline 17 & Albina & P. pinaster & Picard, Lande Corse, France & 7 & 1 & 0 & 0 \\
\hline 22 & Albina & P. pinaster & Tamjout, Morocco & 7 & 2 & 0 & 0 \\
\hline 25 & Albina & P. pinea & Cordillera Central, Spain & 7 & 1 & 0 & 0 \\
\hline 29 & Albina & P. pinea & Idaho, USA & 7 & 2 & 0 & 0 \\
\hline 28 & Albina & P. pinea & Italy & 7 & 1 & 0 & 0 \\
\hline 40 & Albina & P. ponderosa & Central California, USA & 5 & 3 & 1 & 0 \\
\hline 31 & Albina & P. ponderosa & Southern Rockies, USA & 7 & 3 & 0 & 0 \\
\hline 38 & Albina & P. sylvestris & Haguenau Vayriere, France & 6 & 1 & 0 & 0 \\
\hline 24 & Albina & P. sylvestris & Severozapadna, Slovakia & 7 & 2 & 0 & 0 \\
\hline 30 & Albina & P. sylvestris & Sierra de Guadarrama, Spain & 7 & 3 & 0 & 0 \\
\hline 33 & Albina & P. sylvestris & Turkey & 7 & 3 & 0 & 0 \\
\hline 41 & Albina & P. taeda & Georgia, USA & 5 & 3 & 0 & 0 \\
\hline 20 & Albina & P. taeda & Sur de California, USA & 7 & 3 & 0 & 0 \\
\hline 19 & Albina & P. taeda & Virginia, USA & 7 & 1 & 0 & 0 \\
\hline 11 & Irisasi & P. brutia & Alexandropolis, Greece & 7 & 1 & 1 & 0 \\
\hline 15 & Irisasi & P. brutia & Marmaris, Turkey & 7 & 1 & 0 & 1 \\
\hline 14 & Irisasi & P. brutia & Taurus, Turkey & 7 & 1 & 0 & 0 \\
\hline 12 & Irisasi & P. brutia & var. eldarica, Crimea & 7 & 1 & 0 & 0 \\
\hline 9 & Irisasi & P. elliottii & Georgia, USA & 7 & 1 & 0 & 0 \\
\hline
\end{tabular}




\begin{tabular}{|c|c|c|c|c|c|c|c|}
\hline 4 & Irisasi & P. elliottii & Louisiana, USA & 7 & 1 & 0 & 0 \\
\hline 16 & Irisasi & P. nigra & Slogne Vayrières, France & 7 & 3 & 0 & 1 \\
\hline 2 & Irisasi & P. nigra & $\begin{array}{l}\text { subsp. laricio var. corsican, } \\
\text { Haute Serre seed tree orchard, } \\
\text { France }\end{array}$ & 7 & 3 & 0 & 0 \\
\hline 10 & Irisasi & P. pinaster & Mimizan, Landes, France & 7 & 1 & 0 & 0 \\
\hline 1 & Irisasi & P. pinaster & Picard, Lande Corse, France & 7 & 1 & 0 & 0 \\
\hline 13 & Irisasi & P. pinaster & Tamjout, Morocco & 7 & 1 & 0 & 0 \\
\hline 8 & Irisasi & P. pinea & Italy & 7 & 2 & 0 & 0 \\
\hline 5 & Irisasi & P. ponderosa & Oregon, USA & 7 & 4 & 0 & 1 \\
\hline 7 & Irisasi & P. ponderosa & Southern Rockies, USA & 7 & 3 & 0 & 0 \\
\hline 3 & Irisasi & P. sylvestris & Severozapadna, Slovakia & 7 & 4 & 0 & 0 \\
\hline 6 & Irisasi & P. sylvestris & Turkey & 7 & 3 & 0 & 0 \\
\hline 31 & Umbemendi & P.brutia & Marmaris, Turkey & 7 & 2 & 0 & 0 \\
\hline 30 & Umbemendi & P. brutia & Taurus, Turkey & 7 & 3 & 0 & 0 \\
\hline 32 & Umbemendi & P. brutia & var. eldarica, Crimea & 7 & 3 & 1 & 0 \\
\hline 19 & Umbemendi & P. elliottii & Georgia, USA & 7 & 2 & 0 & 0 \\
\hline 29 & Umbemendi & P. elliottii & Louisiana, USA & 7 & 2 & 0 & 0 \\
\hline 21 & Umbemendi & P. nigra & Cazorla Alcaraz, Spain & 7 & 2 & 0 & 0 \\
\hline 20 & Umbemendi & P. nigra & $\begin{array}{l}\text { subsp. laricio var. calabrica, Les } \\
\text { Barnes-Sivens, France }\end{array}$ & 7 & 2 & 0 & 0 \\
\hline 14 & Umbemendi & P. nigra & $\begin{array}{l}\text { subsp. laricio var. corsican, } \\
\text { Slogne Vayrières, France }\end{array}$ & 7 & 3 & 0 & 0 \\
\hline 13 & Umbemendi & P. nigra & $\begin{array}{l}\text { subsp. salzmannii - ESO7b - } \\
\text { Sistema Iberico Meridional, Sur } \\
\text { de Cuenca, Spain }\end{array}$ & 7 & 1 & 0 & 0 \\
\hline 2 & Umbemendi & $P$. pinaster & Cordal de Loba, Spain & 7 & 3 & 0 & 0 \\
\hline 5 & Umbemendi & P. pinaster & Leiria, Portugal & 7 & 1 & 0 & 0 \\
\hline 3 & Umbemendi & P. pinaster & Mimizan, Landes, France & 7 & 4 & 0 & 0 \\
\hline 7 & Umbemendi & P. pinaster & Picard, Lande Corse, France & 7 & 4 & 0 & 0 \\
\hline 8 & Umbemendi & P. pinaster & Serrania de Cuenca, Spain & 7 & 4 & 0 & 0 \\
\hline 4 & Umbemendi & P. pinaster & Sierra de Gredos, Spain & 7 & 2 & 0 & 0 \\
\hline 6 & Umbemendi & P. pinaster & Tamjout, Morocco & 7 & 1 & 0 & 0 \\
\hline 16 & Umbemendi & P. pinea & Italy & 7 & 2 & 0 & 0 \\
\hline 15 & Umbemendi & P. pinea & $\begin{array}{l}\text { Région méditerranéenne, } \\
\text { France }\end{array}$ & 7 & 1 & 0 & 0 \\
\hline 18 & Umbemendi & P. pinea & $\begin{array}{l}\text { Valles del Tietar and Alberche, } \\
\text { Spain }\end{array}$ & 7 & 2 & 0 & 0 \\
\hline 17 & Umbemendi & P. pinea & Vendas Novas, Portugal & 7 & 2 & 0 & 0 \\
\hline 27 & Umbemendi & P. ponderosa & Oregon, USA & 7 & 2 & 0 & 0 \\
\hline 28 & Umbemendi & P. ponderosa & Southern Rockies, USA & 7 & 2 & 0 & 0 \\
\hline 23 & Umbemendi & P. sylvestris & Montes universales, Spain & 7 & 2 & 0 & 0 \\
\hline 24 & Umbemendi & P. sylvestris & Pinhal da Pedra Bela, Portugal & 7 & 2 & 0 & 0 \\
\hline 12 & Umbemendi & P. sylvestris & Scotland & 7 & 1 & 0 & 0 \\
\hline 26 & Umbemendi & P. sylvestris & Severozapadna, Slovakia & 7 & 1 & 0 & 0 \\
\hline 11 & Umbemendi & P. sylvestris & Sierra de Guadarrama, Spain & 7 & 2 & 0 & 0 \\
\hline 22 & Umbemendi & P. sylvestris & Taborz-Haute Serre, Poland & 7 & 2 & 0 & 0 \\
\hline 25 & Umbemendi & P. sylvestris & Turkey & 7 & 2 & 0 & 0 \\
\hline
\end{tabular}




$\begin{array}{llllllll}10 & \text { Umbemendi } & \text { P. taeda } & \text { Georgia, USA } & 7 & 2 & 0 & 0 \\ 9 & \text { Umbemendi } & \text { P. taeda } & \text { South of California, USA } & 7 & 1 & 0 & 0 \\ 1 & \text { Umbemendi } & \text { P. taeda } & \text { Virginia, USA } & 7 & 2 & 0 & 0\end{array}$

\section{Discussion}

In this preliminary study, we report Pinus brutia (Provenance: Alexandropolis, Greece and var. eldarica, Crimea) as a new host species for Lecanosticta acicola, and P. elliottii (Provenance: Georgia, USA) and P. ponderosa (Provenance: Central California, USA) are reported as new host reports for Spain. Dothistroma septosporum was found for the first time in Spain on P. brutia (Provenance: Marmaris, Turkey) and P. ponderosa (Provenance: Oregon, USA), and was also detected infecting $P$. nigra (Provenance: Slogne Vayrières, France).

Pinus nigra, $P$. ponderosa and $P$. elliottii are known to be susceptible to brown spot needle blight and Dothistroma needle blight $[2,5,6]$. Pinus brutia is a pine species closely related to P. halepensis Mill. and adapted to Mediterranean regions where it has been extensively planted [16]. $D$. septosporum was detected on P. brutia in Greece and Turkey $[17,18]$, but based on EPPO and the recent review by van der Nest et al. [5], this is the first report of L. acicola on this Pinus species. Three of the four P. brutia provenances screened positive for L. acicola and/or D. septosporum. The Mediterranean nature of this host could be affecting its adaptability to the Atlantic area and predisposing it to fungal infections. It would be interesting to monitor these species and provenances during the next few years. The absence of $D$. pini in the analyzed samples may be explained by the low detection rates previously observed in the region [9].

It was observed that the level of defoliation was not always related to the positive detection of the pathogenic organisms. There were cases with low levels of defoliation and positive detections of D. septosporum or L. acicola, and vice versa (Table 1). Other biotic and/or abiotic factors (stress caused by insects flooding, soil nutrient deficiencies, etc.) that can lead to defoliation may be involved. Even though Phytophthora sp. were not detected in the current survey, monitoring for these pathogens will continue in the future.

The purpose of this survey was to determine the presence of Lecanosticta acicola, Dothistroma spp. and Phytophthora as causal agents of the needle defoliation symptoms observed on Pinus species in three arboreta located in the North of Spain. The arboreta were established as part of the project REINFFORCE to study the impact of the climatic change on forests of the Atlantic region where different species and provenances were planted to determine their adaptability. Arboreta were mainly surrounded by $P$. radiata and $P$. nigra plantations that were severely infected with Dothistroma spp. and L. acicola. Since the seedlings were sent from the nurseries with their phytosanitary certificate, it is plausible to think that natural infections were the cause of the disease outbreak. In addition, the lack of a positive identification of the pathogens could be due to the low detection level of conventional PCR, which might not be sensitive enough to pick up recent infections, as opposed to predicting the host species exhibit some level of resistance. To better define the possible tolerance of the examined pine trees against these diseases, a controlled inoculation assay is needed. 


\section{Conclusion}

In this preliminary study, we report the detection of Lecanosticta acicola in Pinus brutia (Alexandropolis, Greece and var. eldarica, Crimea), a new host species for this pathogen at a global scale. For the first time in Spain, L. acicola was found on P. elliottii (Georgia, USA) and P. ponderosa (Central California, USA) and Dothistroma septosporum was found on P. brutia (Marmaris, Turkey), $P$. ponderosa (Oregon, USA) and P. nigra (Slogne Vayrières, France). Knowledge regarding differences in host-tolerance is fundamental to manage a disease as these pathogens can lead to serious economic, social and environmental losses. Forestry companies and European organizations need to re-enforce or establish breeding programmes to identify disease-tolerant planting stock.

\section{Acknowledgments:}

To implement this study the authors were funded by their respective institutions and by the Project RTA 201700063-C04-03 INIA and the Project: Healthy Forest: LIFE14 ENV/ES/000179.

Author Contributions: Nebai Mesanza, Rosa Raposo, Margarita Elvira-Recuenco, Laura Hernandez-Escribano, Irene Barnes, Ariska Van de Nest and Eugenia Iturritxa developed conceptual ideas, designed the study and wrote the paper. Nebai Mesanza and Eugenia Iturritxa analysed the samples in the laboratory, and conduced data analysis. María Teresa Pascual, Iskander Barrena, Unai San Martín implemented the sampling and the defoliation evaluation of the trees. Alejandro Cantero also contributed to develop conceptual ideas.

Conflicts of Interest: The authors declare no conflict of interest.

\section{References}

1. Drenkhan, R.; Tomešová-Haataja, V.; Fraser, S.; Bradshaw, R.E.; Vahalík, P.; Mullett, M.S.; MartínGarcía, J.; Bulman, L.S.; Wingfield, M.J.; Kirisits, T.; Cech, T.L.; Schmitz, S.; Baden, R.; Tubby, K.; Brown, A.; Georgieva, M.; Woods, A.; Ahumada, R.; Jankovský, L.; Thomsen, I.M.; Adamson, K.; Marçais, B.; Vuorinen, M.; Tsopelas, P.; Koltay, A.; Halasz, A.; La Porta, N.; Anselmi, N.; Kiesnere, R.; Markovskaja, S.; Kačergius, A.; Papazova-Anakieva, I.; Risteski, M.; Sotirovski, K.; Lazarević, J.; Solheim, H.; Boroń, P.; Bragança, H.; Chira, D.; Musolin, D.L.; Selikhovkin, A.V.; Bulgakov, T.S.; Keča, N.; Karadžić, D.; Galovic, V.; Pap, P.; Markovic, M.; Poljakovic Pajnik, L.; Vasic, V.; Ondrušková, E.; Piškur, B.; Sadiković, D.; Diez, J.J.; Solla, A.; Millberg, H.; Stenlid, J.; Angst, A.; Queloz, V.; Lehtijärvi, A.; Doğmuş-Lehtijärvi, H.T.; Oskay, F.; Davydenko, K.; Meshkova, V.; Craig, D.; Woodward, S.; Barnes, I. Global geographic distribution and host range of Dothistroma species: a comprehensive review. Forest Pathol. 2016, 46, 408-442.

2. van der Nest, A.; Wingfield, M.; Janoušek, J.; Barnes, I. Lecanosticta acicola: A growing threat to expanding global pine forests and plantations. Mol. Plant Pathol. 2019, 10, 1327-1364.

3. Martínez, J. B. Una grave micosis del pino observada por primera vez en España. Bol. R. Soc. Esp. Hist. Nat. Sec. Geol. 1933, 33, 25-30.

4. Martínez, J. B. Las micosis del Pinus insignis en Guipúzcoa. Publ. Inst. for. Invest. Exp. 1942, 13, 1-72.

5. Barnes, I.; van der Nest, A.; Mullett, M.S.; Crous, P.W.; Drenkhan, R.; Musolin, D.L.; Wingfield, M.J. Neotypification of Dothistroma septosporum and epitypification of D. pini, causal agents of Dothistroma needle blight of pine. Forest Pathol. 2016, 46, 388-407.

6. Mullett, M.S.; Adamson, K.; Bragança, H.; Bulgakov, T.S.; Georgieva, M.; Henriques, J.; Jürisoo,L.; Laas, M.; Drenkhan, R. New country and regional records of the pine needle blight pathogens Lecanosticta acicola, Dothistroma septosporum and Dothistroma pini. Forest Pathol. 2018, 48, e12440.

7. Janoušek, J.; Wingfield, M.J.; Marmolejo Monsivais, J.G.; Jankovský, L.; Stauffer, C.; Konečný, A.; Barnes, I. Genetic analyses suggest separate introductions of the pine pathogen Lecanosticta acicola into Europe. Phytopathol. 2016, 106(11), 1413-1425.

8. Sadiković, D.; Piškur, B.; Barnes, I.; Hauptman, T.; Diminić, D.; Wingfield, M.J.; Jurc, D. Genetic diversity of the pine pathogen Lecanosticta acicola in Slovenia and Croatia. Plant Pathol. 2019, 68, 11201131. 
9. Ortíz de Urbina, E.; Mesanza, N.; Aragonés, A.; Raposo, R.; Elvira-Recuenco, M.; Boqué, R.; Patten, C.; Aitken, J.; Iturritxa, E. Emerging needle blight diseases in Atlantic Pinus ecosystems of Spain. Forests 2017, 8(1),18.

10. Scott, P.; Williams, N. Phytophthora diseases in New Zealand forests. N. Z. J. For. 2014, 59(2),14-21.

11. Durán, A.; Gryzenhout, M.; Slippers, B.; Ahumada, R.; Rotella, A.; Flores, F.; Wingfield, B.D.; Wingfield, M.J. Phytophthora pinifolia sp. nov. associated with a serious needle disease of Pinus radiata in Chile. Plant Pathol. 2008, 57, 715-27.

12. Hansen, E.M. Phytophthora species emerging as pathogens of forest trees. Curr. For. Rep. 2015, 1, 1624.

13. Dick, M.A.; Williams, N.M.; Bader, M.K.F.; Gardner, J.F.; Bulman, L.S. Pathogenicity of Phytophthora pluvialis to Pinus radiata and its relation with red needle cast disease in New Zealand. N. Z. J. For. Sci. 2014, 44, 6

14. Bulman, L.; Ganley, R.J.; Dick, M. Needle diseases of radiata pine in New Zealand. Scion Client Report No. 13010; Forest Biosecurity Research Council: Rotorua, New Zealand, 2008.

15. Ioos, R.; Fabre, B.; Saurat, C.; Fourrier, C.; Frey, P.; Marçais, B. Development, comparison, and validation of real-time and conventional PCR tools for the detection of the fungal pathogens causing brown spot and red band needle blights of pine. Phytopathol. 2010, 100, 105-114.

16. Mauri, A.; Di Leo, M.; de Rigo, D.; Caudullo, G. Pinus halepensis and Pinus brutia in Europe: distribution, habitat, usage and threats. In European Atlas of Forest Tree Species; San-Miguel-Ayanz, J., deRigo, D., Caudullo, G., Houston Durrant, T., Mauri, A. Eds.; Publ. Off. EU, Luxembourg, 2016; p. e0166b8.

17. Tsopelas, P.; Barnes, I.; Soulioti, I.; Wingfield, M.J. Dothistroma septosporum identified in Greece on Pinus brutia and Pinus nigra plantations. APS 2013, 97(9), 1247.

18. Tunali, Z.; Doğmuş-Lehtijärvi, T.; Oskay, F. Burdur İli Kızılçam (Pinus brutia Ten.) Ormanlarında İbre Yanıklı̆̆1 ve Dökümüne Neden Olan Fungal Etmenlerin Moleküler Yöntemlerle Tespiti. J. Nat. Appl. Sci. 2018, 22, 628-636. 